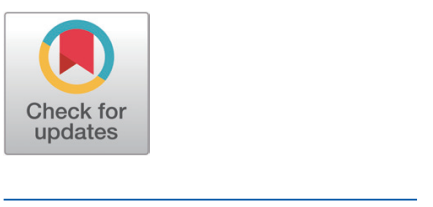

Received: Apr 30, 2021

Revised: Jun 24, 2021

Accepted: Jul 14, 2021

\#These authors contributed equally to this work.

*Corresponding author

Seongwon Seo

Division of Animal and Dairy Sciences,

Chungnam National University,

Daejeon 34134, Korea.

Tel: +82-42-821-5787

E-mail: swseo@cnu.kr

Copyright (c) 2021 Korean Society of Animal Sciences and Technology.

This is an Open Access article distributed under the terms of the

Creative Commons Attribution

Non-Commercial License (http:// creativecommons.org/licenses/by$\mathrm{nc} / 4.0 /$ ) which permits unrestricted non-commercial use, distribution, and reproduction in any medium, provided the original work is properly cited.

ORCID

Hamin Kang

https://orcid.org/0000-0001-5208-5489

Mingyung Lee

https://orcid.org/0000-0001-8952-9725

Seoyoung Jeon

https://orcid.org/0000-0002-8276-317X

Sang Moon Lee

https://orcid.org/0000-0002-2054-1213

Ju Hwan Lee

https://orcid.org/0000-0002-4914-5361

Seongwon Seo

https://orcid.org/0000-0002-4131-0545

Competing interests

No potential conflict of interest relevant to this article was reported.

Funding sources

This research was supported by an academic research fund from Chungnam National University.

\section{Effect of flaking on the digestibility of corn in ruminants}

\author{
Hamin Kang ${ }^{1 \#}$, Mingyung Lee ${ }^{1 \#}$, Seoyoung Jeon ${ }^{1}$, Sang Moon Lee ${ }^{2}$, \\ Ju Hwan Lee ${ }^{2}$ and Seongwon Seo ${ }^{1 *}$ \\ ${ }^{1}$ Division of Animal and Dairy Sciences, Chungnam National University, Daejeon 34134, Korea \\ ${ }^{2}$ Jeil Feed, Daejeon 34365, Korea
}

\section{Abstract}

In this study, we aimed to assess the effect of flaking on the nutrient digestibility of corn grain in ruminants. In this regard, in vitro rumen fermentation, in situ rumen degradability, and in vivo metabolic experiments were performed. The automated gas production technique was used for the in vitro fermentation experiments. Six types of corn flakes with various degrees of gelatinization $(32 \%, 41 \%, 48 \%, 66 \%, 86 \%$, and $89 \%)$ were ground and incubated in rumen fluid to measure rumen fermentation characteristics and digestion rate. The in situ degradability of ground corn, whole corn, and corn flakes with $62 \%$ and $66 \%$ gelatinization was measured by incubation in the rumen of two cannulated Holstein cows. In vivo metabolic experiments were performed using 12 crossbred goats $(29.8 \pm 4.37 \mathrm{~kg})$ using a $3 \times 3$ Latin square design. The dietary treatments consisted of ground corn and flaked corn with $48 \%$ or $62 \%$ gelatinization. In vitro experiments showed that as the degree of gelatinization increased, the digestion rate increased linearly, while the discrete lag time decreased linearly $(p<0.05)$. The effective rumen dry matter degradability, determined by in situ fermentation, was $37 \% p$ lower in corn flakes than ground corn, assuming a passage rate of $6 \% / h(p<0.01)$, and there was no difference between the two flakes. In the in vivo experiment, there was no difference in dry matter intake, average daily gain, feed efficiency, and nitrogen utilization among the treatment groups $(p>0.05)$; however, the crude fat digestibility was lower for corn flakes than for ground corn $(p<0.05)$. To summarize, the rate of fermentation of corn flakes increased as the degree of gelatinization increased. However, non-ground corn flakes had lower rumen digestibility and did not improve in vivo apparent nutrient digestibility, compared with ground corn. In contrast to the assumption that flaked corn provides more energy to ruminant animals than ground corn, we conclude that the digestibility and energy value of corn flakes are lower than those of ground corn if mastication does not sufficiently reduce the particle size of corn flakes.

Keywords: Corn, Gelatinization, Particle size, Ruminant, Digestibility

\section{INTRODUCTION}

Corn is the major grain for concentrate feed in cattle diets. It is the primary energy source for livestock, and its primary constituent is starch [1]. Corn is surrounded by a hard pericarp, resistant to bacteria and enzymes; the starch-protein matrix in the granules is firmly bound, so it is degraded more slowly than 
Acknowledgements

The authors acknowledge the generous and helpful cooperation by Jeil Feed.

Availability of data and material Upon a reasonable request, the datasets of this study can be available from the corresponding author.

Authors' contributions Conceptualization: Lee SM, Lee JH, Seo S. Data curation: Jeon S, Seo S. Formal analysis: Kang $\mathrm{H}$, Lee $\mathrm{M}$, Jeon $\mathrm{S}$. Methodology: Lee SM, Lee JH. Validation: Lee M, Jeon S. Investigation: Kang $\mathrm{H}$, Lee $\mathrm{M}$, Jeon $\mathrm{S}$. Writing - original draft: Kang $\mathrm{H}$, Lee $\mathrm{M}$. Writing - review \& editing: Lee M, Seo S.

Ethics approval and consent to participate This study was carried out in strict accordance with the recommendations in the Guide for the Care and Use of Laboratory Animals of the Korean Association For Laboratory Animals. All experimental procedures were reviewed and approved by the Committee on the Ethics of Animal Experiments of the Chungnam National University (Approval Number: CNU-01022) barley and wheat [2,3]. However, the digestibility of corn can be increased through processing [1,4], and various processing methods have been suggested in this regard.

Processing methods can be classified as non-thermal and thermal. Non-thermal processing includes grinding and dry rolling, while thermal processing includes steam-rolling, steam-flaking, and roasting [5]. Grinding causes mechanical destruction of the pericarp, reduces particle size, and increases surface area, facilitating the attachment of microorganisms. It was reported that grinding increases ruminal starch digestibility by approximately 21\%p compared to whole corn [6]. The improvement in starch digestibility increases as the degree of grinding increases (i.e., as the particle size decreases) [7-9].

Steam-flaking with high temperature and moisture also increases ruminal starch digestibility of corn grain. Steam-flaking, or simply flaking, also cracks the pericarp and starch granules to some extent, but more importantly, it gelatinizes the starch granules and increases degradation by bacteria and enzymes $[3,4,10,11]$. Flaked corn had a 30\%p higher ruminal starch digestibility than whole corn [12], which can be more, depending on the degree of flaking [1,13]. Early studies that compared ground corn and steam-flaked corn in dairy or beef cattle reported that rumen starch digestibility was higher in steam-flaked corn than in ground corn [14-17], and feed efficiency was also higher in animals fed with steam-flaked corn [18-20]. Thus, it is commonly assumed that flaked corn is more degradable and provides more energy to ruminant animals than ground corn [21]. However, some studies have reported contrasting results that there was no difference in performance, such as growth and feed efficiency, between ground corn and steam flaked corn [22-25]. Thus, more comprehensive research is needed on the effects of flaking on the ruminal and total tract digestibility of corn and the consequent animal productivity. Furthermore, flaking corn requires additional costs, which increase as the degree of processing increases [26]. Therefore, the effect of degrees of flaking on the degradability of flaked corn also needs to be addressed.

The objectives of this study were two-fold: 1) to evaluate the effect of flaking on ruminal fermentability and degradability of corn grain and 2) to compare ruminal and total tract degradability of flaked corn with that of ground corn. In the present study, in vitro fermentation experiments, in situ degradability experiments, and in vivo metabolic experiments using goats were performed.

\section{MATERIALS AND METHODS}

This study was conducted at the Center for Animal Science Research, Chungnam National University, Korea. Animal use and the protocols for this experiment were reviewed and approved by the Chungnam National University Animal Research Ethics Committee (CNU-01022).

\section{Flaked corn samples}

Seven flaked corn samples, along with whole and ground corn, were used in this study. Corn samples were obtained from multiple feed manufacturers to cover a wide range of flaking processes. Sampling was performed within a week to minimize seasonal and origin variations.

\section{Chemical analysis}

The dry matter (DM; \#930.15), crude protein (CP; \#927.02), crude fiber (CF; \#962.09), and ash (\#942.05) content in feces, feed refusals, and experimental diets were determined as described by AOAC [27]. Ether extract (EE; \#2003.05) content was determined as described by AOAC [28], and $\mathrm{Ca}$ and $\mathrm{P}$ (\#985.01) content was determined as described by AOAC [29]. The starch (a.k.a, naive starch) content of feedstuffs was determined according to the Ewers polarimetric 
method (ISO 10520:1997). The extent of starch gelatinization was measured by analyzing the proportion of gelatinized starch to naive starch using an enzymatic method similar to that described by Zhu et al. [30]. More in detail, $0.5 \mathrm{~g}$ of ground corn with a particle size of $0.5 \mathrm{~mm}$ was boiled in $25 \mathrm{~mL}$ distilled water for 15 minutes and immediately cooled down. Another $0.5 \mathrm{~g}$ sample was added to $25 \mathrm{~mL}$ distilled water at ambient temperature for $15 \mathrm{~min}$. Next, $10 \mathrm{~mL}$ of acetate buffer and $5 \mathrm{~mL}$ of starch saccharification enzyme solution were added to each beaker, and the samples were then incubated at $40^{\circ} \mathrm{C}$ for $70 \mathrm{~min}$. After incubation, $5 \mathrm{~mL}$ of $25 \%$ trichloroacetate was added to cease the reaction, and the mixture was cooled for $10 \mathrm{~min}$. After cooling, distilled water was added to a final volume of $100 \mathrm{~mL}$, and the mixture was filtered through a filter paper (No. 5A). After the filtrate was transferred to a microtube, and the amount of glucose was measured using a YSI 2900 (YSI, Yellow Springs, OH, USA).

\section{In vitro ruminal fermentation kinetics (Exp. 1)}

The effect of gelatinization of flaked corn on in vitro ruminal fermentation kinetics was assessed using an automated gas production system [31]. Gelatinization refers to the amount of gelatinized starch as a percentage of the naive starch. The extent of gelatinization of flaked corn in each sample was 32\% (Flake_32), 41\% (Flake_41), 48\% (Flake_48), 66\% (Flake_66), 86\% (Flake_86), and 89\% (Flake_89) (Table 1). The samples were ground to pass through a $2 \mathrm{~mm}$ screen using a cyclone mill (Foss, Hillerød, Denmark). Subsequently, $0.2 \mathrm{~g}$ of the substrate was weighed into a serum bottle in triplicate for each treatment group, and $16 \mathrm{~mL}$ of in vitro buffer solution prepared as described by Goering and Van Soest [32] was added under strictly anaerobic conditions. After adding the anaerobic buffer solution, the bottles were capped with a butyl rubber stopper and sealed with an aluminum cap to maintain anaerobic conditions.

Before morning feeding, rumen fluid was collected from two non-pregnant and non-lactating Holstein cows, fitted with a permanent fistula. The animals were fed $700 \mathrm{~g} / \mathrm{kg}$ corn silage and 300 $\mathrm{g} / \mathrm{kg}$ commercial concentrate mix twice daily (Table 2). After collection, the two rumen fluids

Table 1. Analyzed chemical composition (g/kg DM or as stated) of corn samples used for this study

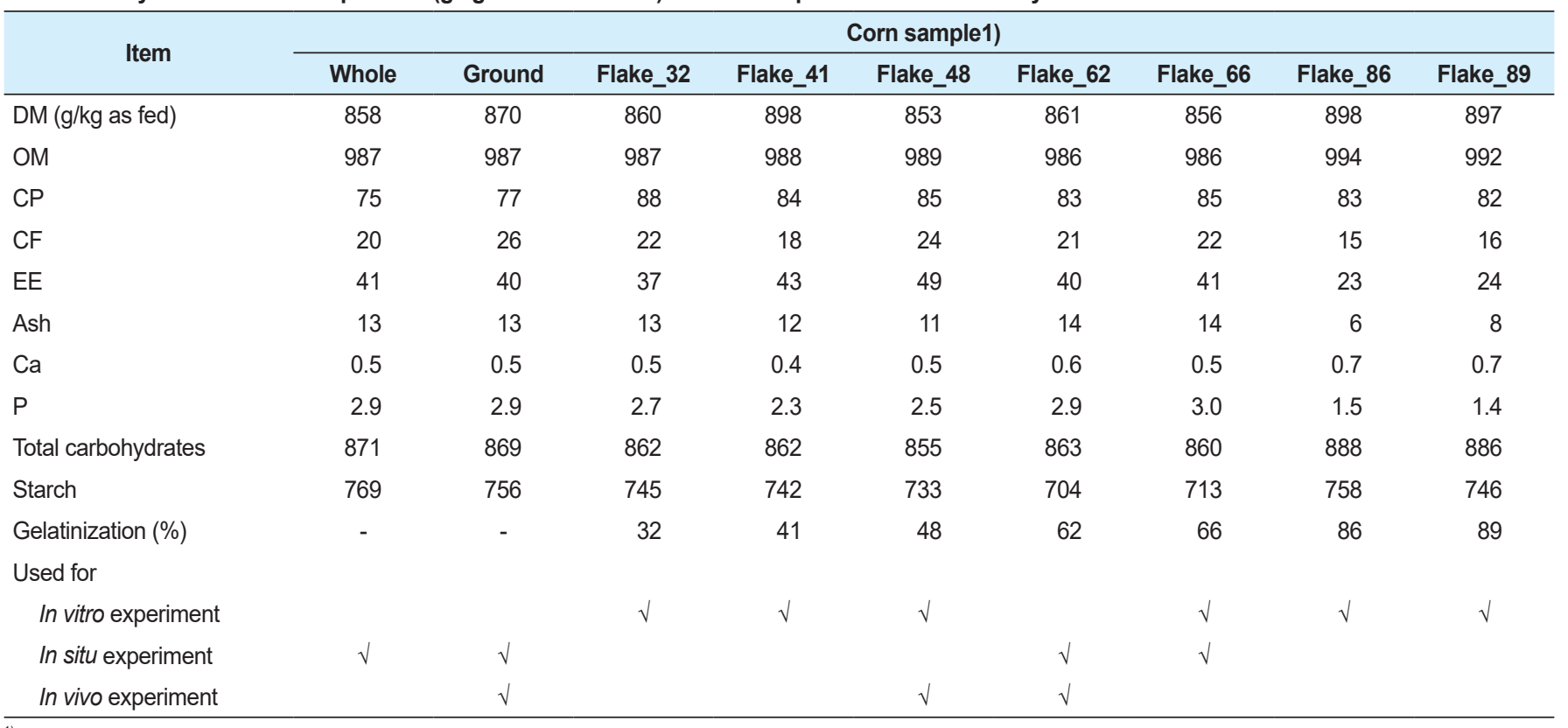

1)Whole, whole corn; Ground, ground corn; Flake_(\% gelatinization).

$\mathrm{DM}$, dry matter; $\mathrm{OM}$, organic matter; $\mathrm{CP}$, crude protein; $\mathrm{CF}$, crude fiber; $\mathrm{EE}$, ether extract. 
Table 2. Analyzed chemical composition ( $\mathrm{g} / \mathrm{kg} \mathrm{DM}$ or as stated) of the corn silage and commercial concentrate mix fed to two fistulated Holstein

\begin{tabular}{lcc}
\hline & \multicolumn{2}{c}{ Treatment } \\
\cline { 2 - 3 } Item & Corn silage & Concentrate mix \\
\hline DM (g/kg as fed) & 232 & 878 \\
OM & 922 & 941 \\
aNDF & 527 & 339 \\
ADF & 338 & 192 \\
CP & 121 & 171 \\
EE & 27 & 35 \\
Ash & 78 & 59 \\
NFC & 247 & 396 \\
Total carbohydrates & 774 & 735 \\
Starch & 79 & 346 \\
Ca & 3.7 & 10.8 \\
P & 3.5 & 5.0 \\
\hline DM, dry matter; OM, organic matter; aNDF, neutral detergent fiber analyzed with a heat-stable amylase and expressed inclusive \\
of residual ash; ADF, acid detergent fiber; CP, crude protein; EE, ether extract; NFC, non-fibrous carbohydrate.
\end{tabular}

were mixed, placed in an icebox, delivered to the laboratory within an hour, and filtered through eight layers of sterilized cheesecloth and glass wool while maintaining strict anaerobic conditions. Subsequently, strained rumen fluid was transferred into a serum bottle and stabilized for 1-2 $\mathrm{h}$ in an incubator at $39^{\circ} \mathrm{C}$. The substrate and in vitro buffer solution in the serum bottle were inoculated with $4 \mathrm{~mL}$ of the strained rumen fluid and incubated for $48 \mathrm{~h}$.

The pressure generated by the gas accumulated in the headspace of the serum bottle was automatically measured every 20 minutes over $48 \mathrm{~h}$ of incubation using a pressure sensor. Fermentation kinetics were analyzed using a single-pool and single-lag exponential model as follows:

$$
\begin{gathered}
V_{t}=0 \quad(0 \leq T<L) \\
V_{t}=V_{\max } \times\left(1-\exp \left(-k_{d} \times(t-L)\right) \quad(T \geq L)\right.
\end{gathered}
$$

where $V_{t}$ is the total gas production at time $t(\mathrm{~mL}), t$ is the time after initiation of incubation (h), $L$ is the discrete lag time (h), $k_{d}$ is the fractional rate of gas production $\left(\mathrm{h}^{-1}\right)$, and $V_{\text {max }}$ is the asymptotic gas production $(\mathrm{mL})$.

After $48 \mathrm{~h}$ of incubation, the $\mathrm{pH}$ of the fermentation fluid in the bottle was measured, and neutral detergent fiber (NDF), analyzed using a heat-stable amylase and expressed inclusive of residual ash, was determined to estimate true dry matter digestibility (TDMD) as described by Goering and Van Soest [32].

$$
\operatorname{TDMD}(\%)=\frac{\text { Initial DM }-(\text { Residue NDF }- \text { blank NDF })}{\text { Initial DM }} \times 100
$$

\section{In situ ruminal dry matter and starch degradability (Exp. 2)}

The in situ ruminal digestion experiment was performed using two cannulated, non-lactating Holstein cows. Whole-shelled corn (whole), ground corn (ground), and two unground intact flaked corns (62\% gelatinized flaked corn [Flake_62] and 66\% gelatinized flaked corn [Flake_66]) underwent in situ ruminal degradation. The intact corn samples were not ground to assess the degradability of the corn samples without reducing their particle size by mastication. Ground corn 
was ground to pass through a $2 \mathrm{~mm}$ sieve. Seven sets of triplicate nylon bags $(10 \times 20 \mathrm{~cm}$, pore size $50 \mu \mathrm{m}$, Ankom Technology, Macedon NY, USA) containing $20 \mathrm{~g}$ (with a surface area of $15 \mathrm{mg}$ / $\mathrm{cm}^{2}$ ) of the corn samples were placed in the ventral rumen of each Holstein cow. The bags were removed at the end of each incubation period $(0,3,6,9,12,24$, and $48 \mathrm{~h})$ and washed with cold tap water until the water appeared clear. Three bags from each time period were dried at $65^{\circ} \mathrm{C}$ for $72 \mathrm{~h}$ and weighed to determine in situ DM degradability (DM; \#930.15) [28]. The starch content of the residue was also analyzed.

In situ rumen DM degradability was estimated by applying the time-series data to the model of Ørskov and McDonald [33] as follows:

$$
Y=a+b\left(1-\exp ^{-k_{d} \times t}\right)
$$

where $a$ is the soluble fraction, $b$ is the slowly degradable fraction (potentially degradable), $k_{d}$ is the fractional rate of disappearance (per hourh), and $t$ is the time of incubation (h).

The effective degradability (ED) was calculated as:

$$
Y=a+b\left(\frac{k_{d}}{k_{d}+k_{p}}\right)
$$

where $Y$ is the potential degradability, $a$ is the soluble fraction, $b$ is the slowly degradable fraction, $k_{\mathrm{d}}$ is the fractional rate of degradation, and $k_{\mathrm{p}}$ is the fractional rate of passage (assumed to be 0.04 , 0.06 , and $\left.0.08 \mathrm{~h}^{-1}\right)$.

In vivo nutrient digestibility and nitrogen metabolism (Exp. 3)

\section{Experimental design, animals, and diets}

A total of 12 growing crossbreed goats (Korean native goat $\times$ Boer goat, $29.8 \pm 4.37 \mathrm{~kg}$, eight months old) were used for this study. A replicated-crossover design with three periods and three treatments was used. Each period lasted for three weeks, with 17 days for adaptation and four days of sampling. The wash-out period was set for one week between each period to minimize possible carry-over effects. During this period, goats were fed a control diet. Goats were housed in individual metabolic cages in an environmentally controlled animal research facility. All goats were male and castrated two weeks before the start of the experiment. Goats were randomly allocated and received different treatments during each experimental period. To counteract possible carry-over effects, the sequences of the treatment were randomized and balanced to increase the probability of every possible treatment [34]. Ground corn supplementation was used as a control. Ground corn was replaced by flaked corn (Flake_48, 48\% gelatinized; Flake_62, 62\% gelatinized) in the concentrate mix for other treatments. To meet the NRC [35] requirements for indigenous goat diets were formulated comprising $40 \%$ oat hay and $60 \%$ concentrate mix (Table 3 ). The goats were fed twice daily at 08:00 and 18:00 h, with half of the amount adjusted to achieve 10\% refusal based on the intake of the previous day. Oat hay chopped to $5 \mathrm{~cm}$ was given before the concentrate mix at each feeding to make the goats consume forage as much as possible before ingesting concentrates. Drinking water was freely accessible to the animals throughout the experiment. Individual daily feed intake was recorded by measuring the feed offered and refusals.

\section{Sample collection and analysis}

Body weights were measured before morning feeding before and after each period. During the sampling period, feed refusals were collected daily, and each experimental diet (oat hay and 
Table 3. Analyzed chemical composition ( $\mathrm{g} / \mathrm{kg}$ DM or as stated) of the oat hay and commercial concentrate mix for in vivo experiments

\begin{tabular}{lccccc}
\hline \multirow{2}{*}{\multicolumn{1}{c}{ Item }} & Forage & & \multicolumn{3}{c}{ Concentrate mix $^{\mathbf{1}}$} \\
\cline { 2 - 5 } \cline { 5 - 6 } & Oat hay & & Ground & Flake_48 & Flake_62 \\
\hline DM (g/kg as fed) & 911 & 890 & 887 & 890 \\
OM & 947 & 917 & 918 & 920 \\
CP & 55 & 189 & 190 & 189 \\
CF & 314 & 109 & 110 & 98 \\
EE & 17 & 55 & 53 & 52 \\
Ash & 53 & 84 & 82 & 80 \\
NFE & 561 & 563 & 565 & 581 \\
Total carbohydrates & 875 & 672 & 675 & 679 \\
Starch & - & 236 & 240 & 249 \\
Ca & 2.4 & 12 & 12 & 12 \\
P & 2.2 & 7 & 7 & 7 \\
\hline
\end{tabular}

${ }^{1)}$ Ground, concentrate mix containing ground corn; Flake_(\% gelatinization).

$\mathrm{DM}$, dry matter; OM, organic matter; $\mathrm{CP}$, crude protein; $\mathrm{CF}$, crude fiber; $\mathrm{EE}$, ether extract; NFE, nitrogen-free extract.

concentrate mix) was sampled. Daily feed refusals and diet samples were pooled for each period and stored at $-20^{\circ} \mathrm{C}$ until subsequent analysis. Total feces and urine from each animal were collected, weighed, and sub-sampled daily before the morning feeding during the sampling period. Urine was collected in a glass bottle containing $200 \mathrm{~mL}$ of $2.8 \% \mathrm{HCl}$ and then stored at $-20^{\circ} \mathrm{C}$ until $\mathrm{N}$ was measured as described by AOAC [28]. Sub-sampled feces, feed refusals, and experimental diets were dried at $60^{\circ} \mathrm{C}$ for $96 \mathrm{~h}$ and ground through a cyclone mill (Foss) fitted with a $1 \mathrm{~mm}$ screen before chemical analysis.

\section{Statistical analysis}

Data were analyzed using PROC MIXED (SAS Institute, Cary, NC, USA). Pair-wise comparisons of the least square means were conducted using the PDIFF option with Tukey-Kramer adjustment. Moreover, whenever applicable, a linear contrast between ground corn and flaked corn was performed. Statistical significance was declared at $p<0.05$, and a trend was discussed at $0.05 \leq p<0.1$.

The linear model used for the analysis of the in vivo experimental data was:

$$
Y_{i j k}=\mu+\alpha_{i}+b_{j}+\tau_{k}+\varepsilon_{i j k}
$$

where $Y_{i j k}$ is an observed dependent variable, $\mu$ is the overall mean, $\alpha_{i}$ is the fixed effect of period, $b_{j}$ is the random effect of animal, $\tau_{\mathrm{k}}$ is the fixed effect of treatment, and $\varepsilon_{\mathrm{ijk}}$ is the unexplained error. Based on the interaction between time period and treatment, the potential carry-over effect was not significant in any of the tested variables. This implied that the response of the goats to treatment was consistent during each period, even though different animals received individual treatment. Thus, the interaction term was omitted from the statistical analysis.

\section{RESULTS}

\section{Effects of the degree of gelatinization on in vitro fermentation of flaked corn grain}

The in vitro fermentation characteristics and kinetic parameters after $48 \mathrm{~h}$ of incubation are presented in Table 4 . The $\mathrm{pH}$ was significantly different between treatments and decreased as the 
Table 4. pH of the cultured medium after 48-hour incubation, true dry matter digestibility of the samples, and kinetic parameters of gas production

\begin{tabular}{|c|c|c|c|c|c|c|c|c|c|}
\hline \multirow{2}{*}{ Item } & \multicolumn{6}{|c|}{ Treatment $^{1)}$} & \multirow{2}{*}{ SEM } & \multicolumn{2}{|c|}{$p$-value } \\
\hline & Flake_32 & Flake_41 & Flake_48 & Flake_66 & Flake_86 & Flake_89 & & Overall & Linear \\
\hline $\mathrm{pH}$ & $6.20^{\mathrm{a}}$ & $6.15^{\mathrm{a}}$ & $6.22^{\mathrm{a}}$ & $6.18^{\mathrm{a}}$ & $6.05^{b}$ & $6.07^{b}$ & 0.017 & $<0.01$ & $<0.01$ \\
\hline TDMD (\%) & 88.7 & 92.3 & 94.0 & 92.4 & 93.0 & 96.1 & 2.89 & 0.500 & 0.099 \\
\hline$V_{\max }(\mathrm{mL})$ & 54.3 & 56.0 & 54.8 & 53.1 & 55.0 & 55.6 & 1.43 & 0.323 & 0.857 \\
\hline$k_{d}\left(\mathrm{~h}^{-1}\right)$ & 0.166 & 0.164 & 0.125 & 0.163 & 0.193 & 0.201 & 0.0233 & 0.219 & 0.046 \\
\hline $\operatorname{Lag}(\mathrm{h})$ & 3.2 & 3.5 & 3.2 & 2.7 & 2.4 & 2.4 & 0.45 & 0.045 & $<0.01$ \\
\hline
\end{tabular}

${ }^{1)}$ Flake_(\% gelatinization).

${ }^{a, b}$ Means that do not have common superscript differ $(p<0.05)$.

TDMD, true dry matter digestibility; $V_{\text {max }}$, maximum volume of gas production; $k_{d}$, fractional rate of gas production.

degree of gelatinization increased $(p<0.01)$. According to the degree of gelatinization, TDMD did not significantly differ $(p>0.05)$. Although there was no significant difference in the maximum gas production $\left(V_{\max }\right)$, the fractional rate of gas production $\left(k_{d}\right)$ linearly increased as the degree of gelatinization increased $(p=0.046)$. Moreover, the discrete lag time (lag) decreased linearly with increasing degree of gelatinization $(p<0.01)$. Consequently, the maximum volume of gas production $\left(V_{\text {max }}\right)$ reached quicker in the higher degree of gelatinization (Fig. 1).

\section{Effects of corn processing on in situ ruminal degradability}

\section{In situ dry matter and starch degradability}

The in situ DM degradability of ground corn was significantly higher than that of the other treatments at all times, whereas DM degradability of whole corn was significantly lower than that of the other treatments at all times $(p<0.05)$ (Fig. 2). There was no statistically significant difference between the two flaked corn samples $(p>0.05)$. The same trend was observed for ruminal starch degradability. The starch degradability of ground corn was higher than that of the other treatments at all times, while that of whole corn was significantly lower than that of the other treatments $(p<0.05)$ (Fig. 3). There was no statistically significant difference in starch degradability between the corn flake treatments $(p>0.05)$.

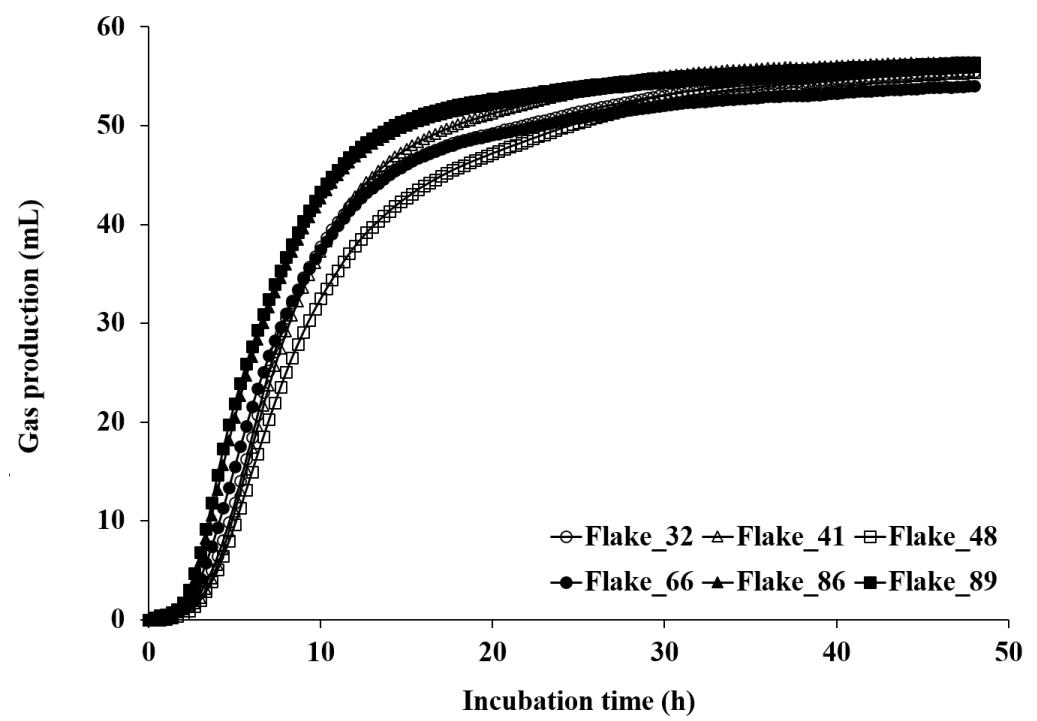

Fig. 1. Gas production profile. Flaked corn with different rate of gelatinization, Flake_(\% gelatinization). 


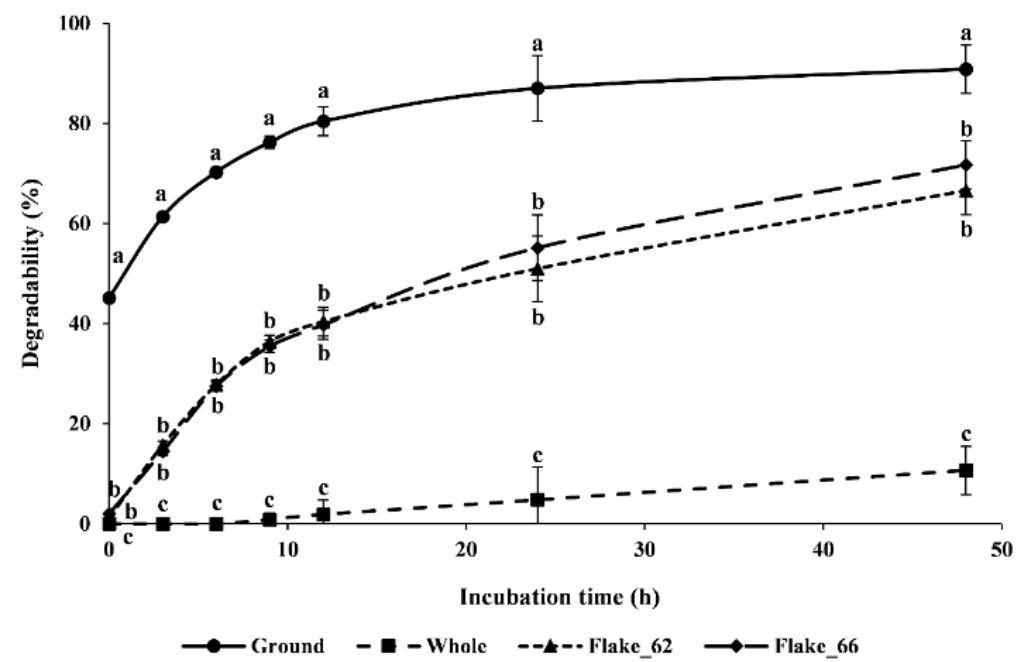

Fig. 2. In situ rumen dry matter degradability. ${ }^{a-c}$ Means that do not have common superscript differ $(p<0.05)$. Ground, ground corn; Whole, whole corn; Flake_(\% gelatinization).

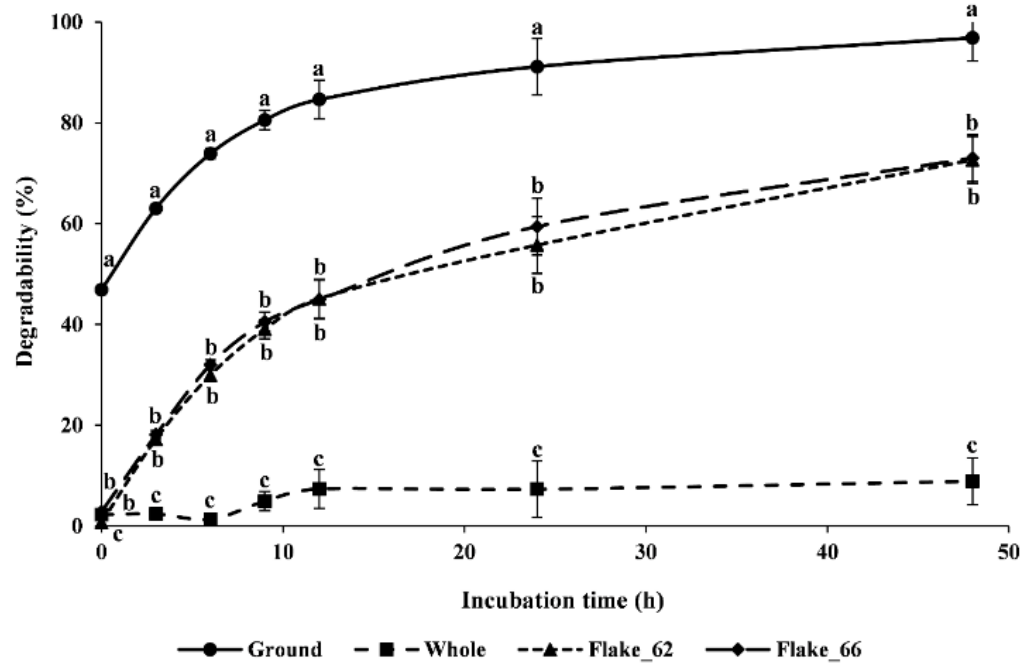

Fig. 3. In situ rumen starch degradability. ${ }^{a-c}$ Means that do not have common superscript differ $(p<0.05)$ Ground, ground corn; Whole, whole corn; Flake_(\% gelatinization).

\section{Ruminal effective dry matter and starch degradability}

The degradation kinetics of the corn samples were assessed without whole corn as only limited degradation occurred with whole corn (Figs. 2 and 3). The proportion of the soluble fraction (fraction A) was greater in ground corn than in flaked corn $(p<0.001)$ (Table 5). The proportion of the slowly degradable (potentially degradable; fraction $\mathrm{B}$ ) fraction tended to be greater in flaked corn than in ground corn $(p=0.07)$. The fractional rate of digestion $\left(k_{d}\right)$ tended to differ among the treatments $(p=0.07)$. Assuming the fractional rate of passage out of the rumen was $0.04,0.06$, and $0.08 \mathrm{~h}^{-1}$, the effective DM degradability was statistically significantly different $(p<0.001)$ for different corn processing methods (ground corn $>$ flaked corn). There was no statistical difference in ED between the two flaked corns with different degrees of gelatinization $(p>0.05)$.

With regard to rumen starch degradability, fraction A was the highest in ground corn $(p<$ 
Table 5. In situ ruminal degradation parameters and effective dry matter ruminal degradability

\begin{tabular}{|c|c|c|c|c|c|c|}
\hline \multirow{2}{*}{ Parameter } & \multicolumn{3}{|c|}{ Treatment $^{1)}$} & \multirow{2}{*}{ SEM } & \multicolumn{2}{|c|}{$p$-value } \\
\hline & Ground & Flake_62 & Flake_66 & & Overall & Ground vs. Flake \\
\hline \multicolumn{7}{|l|}{ Factor $^{2)}$} \\
\hline$A$ & $45.5^{\mathrm{a}}$ & $3.2^{\mathrm{b}}$ & $2.3^{b}$ & 1.17 & 0.002 & 0.001 \\
\hline B & 44.3 & 71.8 & 63.2 & 7.15 & 0.117 & 0.066 \\
\hline$k_{d}$ & 0.14 & 0.06 & 0.08 & 0.021 & 0.204 & 0.114 \\
\hline \multicolumn{7}{|c|}{ Effective degradability ${ }^{3)}$} \\
\hline 0.04 & $79.6^{\mathrm{a}}$ & $46.3^{\mathrm{b}}$ & $44.1^{\mathrm{b}}$ & 3.51 & 0.007 & 0.003 \\
\hline 0.06 & $76.1^{\mathrm{a}}$ & $39.2^{b}$ & $38.1^{b}$ & 2.73 & 0.003 & 0.002 \\
\hline 0.08 & $73.3^{\mathrm{a}}$ & $34.1^{\mathrm{b}}$ & $33.6^{\mathrm{b}}$ & 2.20 & 0.002 & 0.001 \\
\hline
\end{tabular}

${ }^{1)}$ Ground, ground corn; Flake_(\% gelatinization).

${ }^{2)} \mathrm{A}$, soluble fraction (\% DM); $B$, slowly degradable fraction (\% DM); $k d$, fractional rate of degradation $\left(h^{-1}\right)$.

${ }^{3)}$ Effective ruminal degradability when fractional rate of passage is $0.04 \mathrm{~h}^{-1}, 0.06 \mathrm{~h}^{-1}$, and $0.08 \mathrm{~h}^{-1}$, respectively.

${ }^{a, b}$ Means that do not have common superscript differ $(p<0.05)$.

DM, dry matter.

0.001) (Table 6). There was no statistically significant difference between the flaked treatments $(p$ $>0.05)$. The B fraction showed a statistically higher trend in the flaked treatment group than in the ground corn $(p=0.080)$. There was no significant difference in $k_{d}$ between treatments $(p>0.05)$. Effective starch degradability was higher in the flaked treatment than in the ground corn treatment at all assumed flow rates of $0.04,0.06$, and $0.08(p<0.01)$, and there was no significant difference between flaked treatments $(p>0.05)$.

\section{Effects of corn processing on in vivo nutrient digestibility}

There was no statistically significant difference in average daily gain, DM intake, and feed efficiency among the treatments $(p>0.05)$ (Table 7). Crude fat intake was higher in the ground corn group than in the flaked corn group $(p<0.01)$. The apparent total tract digestibility of DM, organic matter, and ash did not differ between the treatments $(p>0.05)$ (Table 8$)$. However, the digestibility of CF was different among the treatments; Flake_48 showed significantly higher crude digestibility than Flake_62 $(p=0.04)$. CP digestibility was different among the treatment groups, and the

Table 6. In situ ruminal degradation parameters and effective starch ruminal degradability

\begin{tabular}{|c|c|c|c|c|c|c|}
\hline \multirow[b]{2}{*}{ Parameter } & \multicolumn{3}{|c|}{ Treatment $^{11}$} & \multirow[b]{2}{*}{ SEM } & \multicolumn{2}{|c|}{$p$-value } \\
\hline & Ground & Flake_62 & Flake_66 & & Overall & $\begin{array}{l}\text { Ground } \\
\text { vs. Flake }\end{array}$ \\
\hline \multicolumn{7}{|l|}{ Factor $^{2)}$} \\
\hline A & $47.2^{\mathrm{a}}$ & $2.1^{\mathrm{b}}$ & $4.0^{b}$ & 1.01 & 0.002 & 0.001 \\
\hline $\mathrm{B}$ & 48.1 & 69.3 & 69.5 & 6.57 & 0.154 & 0.080 \\
\hline$k_{d}$ & 0.13 & 0.08 & 0.08 & 0.015 & 0.185 & 0.098 \\
\hline \multicolumn{7}{|c|}{ Effective degradability ${ }^{3)}$} \\
\hline 0.04 & $83.9^{a}$ & $48.2^{b}$ & $49.7^{b}$ & 3.09 & 0.007 & 0.004 \\
\hline 0.06 & $80.1^{\mathrm{a}}$ & $41.6^{b}$ & $43.0^{b}$ & 2.45 & 0.003 & 0.002 \\
\hline 0.08 & $77.0^{\mathrm{a}}$ & $36.6^{b}$ & $38.1^{b}$ & 2.01 & 0.002 & 0.001 \\
\hline
\end{tabular}

${ }^{1)}$ Ground, ground corn; Flake_(\% gelatinization).

${ }^{2)} \mathrm{A}$, soluble fraction (\% DM); $\mathrm{B}$, slowly degradable fraction (\% DM); $k_{d}$, fractional rate of degradation $\left(\mathrm{h}^{-1}\right)$.

${ }^{3)}$ Effective ruminal degradability when fractional rate of passage is $0.04 \mathrm{~h}^{-1}, 0.06 \mathrm{~h}^{-1}$, and $0.08 \mathrm{~h}^{-1}$, respectively.

${ }^{a, b}$ Means that do not have common superscript differ $(p<0.05)$.

DM, dry matter. 
Table 7. Average daily gains, feed conversion ratio, and nutrient intake of goats fed ground and flaked corn

\begin{tabular}{|c|c|c|c|c|c|c|}
\hline \multirow{2}{*}{ Item } & \multicolumn{3}{|c|}{ Treatment $^{1)}$} & \multirow{2}{*}{ SEM } & \multicolumn{2}{|c|}{$p$-value } \\
\hline & Ground & Flake_48 & Flake_62 & & Overall & Ground vs. Flake \\
\hline Average daily gain (g/d) & 208 & 200 & 193 & 35.9 & 0.91 & 0.71 \\
\hline Feed conversion ratio ${ }^{2)}$ & 7.3 & 6.7 & 7.8 & 1.47 & 0.62 & 0.98 \\
\hline \multicolumn{7}{|l|}{ Nutrient intake (g/d) } \\
\hline Dry matter & 1,112 & 1,115 & 1,106 & 72.6 & 0.92 & 0.94 \\
\hline Organic matter & 1,034 & 1,039 & 1,033 & 67.8 & 0.96 & 0.92 \\
\hline Crude fiber & 225 & 226 & 213 & 13.5 & 0.19 & 0.37 \\
\hline Crude protein & 157 & 153 & 150 & 11.2 & 0.16 & 0.08 \\
\hline Ether extract & $46^{\mathrm{a}}$ & $43^{\mathrm{ab}}$ & $41^{b}$ & 3.0 & $<0.01$ & $<0.01$ \\
\hline Ash & 78 & 76 & 73 & 5.0 & 0.06 & 0.06 \\
\hline
\end{tabular}

${ }^{1)}$ Ground, ground corn; Flake_(\% gelatinization).

${ }^{2)}$ Average daily gain $(\mathrm{g} / \mathrm{d}) / \mathrm{dry}$ matter intake $(\mathrm{g} / \mathrm{d})$.

${ }^{a, b}$ Means that do not have common superscripts significantly differ within the samples $(p>0.05)$.

Table 8. Nutrient digestibility of goats fed ground and flaked corn (\%/d, DM basis)

\begin{tabular}{|c|c|c|c|c|c|c|}
\hline \multirow{2}{*}{ Item } & \multicolumn{3}{|c|}{ Treatment $^{1)}$} & \multirow{2}{*}{ SEM } & \multicolumn{2}{|c|}{$p$-value } \\
\hline & Ground & Flake_48 & Flake_62 & & Overall & Ground vs. Flake \\
\hline Dry matter & 71.34 & 71.43 & 70.80 & 0.500 & 0.43 & 0.61 \\
\hline Organic matter & 73.62 & 73.61 & 73.09 & 0.480 & 0.46 & 0.53 \\
\hline Crude fiber & $63.17^{\mathrm{ab}}$ & $63.89^{a}$ & $60.77^{\mathrm{b}}$ & 0.943 & 0.04 & 0.42 \\
\hline Crude protein & 69.50 & 67.73 & 67.10 & 0.727 & 0.07 & 0.03 \\
\hline Ether extract & $88.25^{\mathrm{a}}$ & $86.28^{b}$ & $86.17^{b}$ & 0.481 & 0.01 & $<0.01$ \\
\hline Ash & 40.73 & 41.04 & 37.51 & 1.474 & 0.19 & 0.42 \\
\hline
\end{tabular}

${ }^{1)}$ Ground, ground corn; Flake_(\% gelatinization).

${ }^{a, b}$ Means that do not have common superscripts significantly differ within the samples $(p<0.05)$.

DM, dry matter.

goats that were fed ground corn had higher $\mathrm{CP}$ digestibility than those fed with flaked corn $(p=$ $0.03)$. Crude fat digestibility was significantly higher in the ground corn group than in the flaked corn groups $(p<0.01)$, even though crude fat intake was greater in control than flaking. Nitrogen intake and nitrogen excreted in urine did not differ between the treatments $(p>0.05)$ (Table 9). In addition, nitrogen retention and biological values were not significantly different $(p>0.05)$.

\section{DISCUSSION}

Flaking causes structural and physical changes in the starch granule and its matrix in corn, and it is widely accepted that flaking increases starch digestibility $[3,4,10,11,36]$ and animal performance $[18,19,26]$. However, some inconsistent results also have been reported [22-25], and it is necessary to study the effect of flaking on the digestibility of corn compared to grinding.

The ruminal fermentability of flaked corn increased as the degree of starch gelatinization increased, based on the in vitro rumen fermentation study. This can be inferred from the results of a significant decrease in $\mathrm{pH}$, increase in $k_{d}$, decrease in the lag time as the gelatinization of corn starch increases. Ruminal $\mathrm{pH}$ is an good indicator of the production of organic acids from ruminal fermentation, and it decreases due to the rapid fermentation of starch [37,38]. Hales et al. [39] also showed that the $\mathrm{pH}$ decreased until $12 \mathrm{~h}$ of in vitro fermentation as the degree of steam-flaking increased (e.g., a decrease in bulk density from $386 \mathrm{~g} / \mathrm{L}$ to $283 \mathrm{~g} / \mathrm{L}$ ). In their study, however, the $\mathrm{pH}$ 
Table 9. Nitrogen utilization of goats fed ground and flaked corn

\begin{tabular}{|c|c|c|c|c|c|c|}
\hline \multirow{2}{*}{ Item } & \multicolumn{3}{|c|}{ Treatment $^{1)}$} & \multirow{2}{*}{ SEM } & \multicolumn{2}{|c|}{$p$-value } \\
\hline & Ground & Flake_48 & Flake_62 & & Overall & Ground vs. Flake \\
\hline Intake (g/d) & 25.19 & 24.45 & 23.94 & 1.798 & 0.16 & 0.08 \\
\hline Feces $(g / d)$ & 7.62 & 7.81 & 7.80 & 0.486 & 0.55 & 0.28 \\
\hline Urine $(g / d)$ & 9.85 & 9.25 & 9.43 & 0.505 & 0.27 & 0.12 \\
\hline Excretion (g/d) & 17.47 & 17.06 & 17.24 & 0.950 & 0.67 & 0.43 \\
\hline Retention (g/d) & 7.72 & 7.39 & 6.70 & 0.970 & 0.33 & 0.27 \\
\hline Retention (\%) & 28.88 & 28.77 & 27.48 & 2.132 & 0.80 & 0.72 \\
\hline Biological value $^{2)}(\%)$ & 41.24 & 42.12 & 40.88 & 2.877 & 0.92 & 0.93 \\
\hline
\end{tabular}

${ }^{1)}$ Ground, ground corn; Flake_(\% gelatinization).

${ }^{2)}($ Intake N - Feces N - Urine N) / (Intake N - Feces N) $\times 100$.

at $48 \mathrm{~h}$ did not differ by the degree of flaking unlike the present study, which was probably because the $\mathrm{pH}$ of cultured fluid after $12 \mathrm{~h}$ in their study was already too low (e.g. $<6.0)$ to differentiate the treatment effect. An increase in the rate of degradation was consistent with Qiao et al. [40] which reported a significantly higher rate of degradation of corn with $78 \%$ gelatinization. A decrease in the lag time may be due to an enhancement of microbial attachement [41]. Steam-flaking destructs the most outer part of corn grain, pericarp. As the degree of flaking increases, the degree of destruction increases, resulting in more rapid attachment of microorganisms [14]. Hence, as the degree of gelatinization increases, attachment by microorganisms becomes more rapid, which makes corn more easily degradable.

Nontheless, a higher degree of flaking did not increase the total digestible portion of the flaked corn. The higher gelatinization did not alter the TDMD or the maximum volume of gas production $\left(V_{\max }\right)$. Since gas production in the rumen occurs due to the degradation of feed by microorganisms, the gelatinization of starch does not increase its availability in the rumen. This is similar to a previous study by Kokić et al. [42] which reported no significant difference in organic matter digestibility as the degree of gelatinization increased from $21 \%$ to $64 \%$. Therefore, an increase in the degree of flaking likely facilitates attachment of microorganisms and increases the rate of ruminal degradation of flaked corns without altering their potential of ruminal degradation.

The availability of corn was more affected by the particle size than the degree of gelatinization. Solubility of unground flaked corn is almost zero, which was reflected in the zero A fraction. Mainly because of this, the effective degradability of starch in flaked corn was 34.3\%p-39.6\%p less than that of ground corn even though insoluble but degradable fraxction (B fraxction) of flaked corn was 21.3\%p higher than ground corn. Thus, particle size plays a significant role in ruminal degradability of corn grain, and without sufficient reduction in particle size, ruminal starch degradability of corn grain can be low even after intensive gelatinization. This result is consistent with previous studies. Lee et al. [11] reported that $1 \mathrm{~mm}$ ground corn had about 35\% higher in situ DM degradability than intact flaked corn (not ground) after $48 \mathrm{~h}$ of in situ rumen fermentation. $4 \mathrm{~mm}$ ground corn showed a high degradability than intact flaked corn at $12 \mathrm{~h}$ and afterward, and eventually showed a 14\%p higher degradability. However, in a previous in vivo experiment [43], calves fed with cracked ( $2.83 \mathrm{~mm}$ of mean particle size) and intact corns showed no significant difference in apparent digestibility. It was observed that the particle size is reduced through mastication by animals, and the reduced size helps to increase the availability. Another in situ rumen fermentation study reported that corn masticated by cattle also increased fraction A by about 4\%p and fraction B by about 47\%p compared to intact whole corn [3]. This is consistent with our result where, whole corn barely degraded, and the difference in degradability with ground corn 
was about 70\%p (data not shown). Therefore, the grain particle size, which significantly influences the increase in grain availability, is considerably reduced by mastication, so the extent of mastication should be considered as an important factor in feed availability. However, the reduction in particle size by mastication may be a rate-limiting step in the digestion of flaked corn in the rumen, and if mastication is not sufficient to reduce the particle size of feeds, flaked corn may have lower availability than ground corn.

The nutritional value of ground corn might be higher than that of flaked corn. In the in vivo experiment, ground corn showed higher digestibility of $\mathrm{EE}$ and $\mathrm{CP}$, and $\mathrm{EE}$ intake than flaked corn (Tables 7 and 8). The higher digestibility of $\mathrm{EE}$ and $\mathrm{CP}$ in ground corn implies that there is more potential value that can be used by animals. These differences in $\mathrm{CP}$ digestibility between ground corn and flaked corn is apparently caused by changes in the rumen availability of $\mathrm{CP}$ in corn during flaking. The amount of rumen degradable protein (RDP) decreases during flake processing [44-46], and this decrease in RDP alters the activity of microorganisms in the rumen and consequently affects the total tract $\mathrm{CP}$ digestibility [47]. In previous studies that used goats, $\mathrm{CP}$ digestibility decreases significantly as the amount of RDP in the diet decreases [48,49]. In addition to the high $\mathrm{CP}$ digestibility of ground corn, the high digestibility of $\mathrm{EE}$ appears to be affected by $\mathrm{EE}$ intake. Previous studies reported that the digestibility of fat increases quadratically as the intake of fat increases, which is consistent with our results [50-53]. However, the result of high EE intake in ground corn treatments contrasts with early studies that flaking increases the total tract digestibility of nutrients $[16,19,54]$. Others reported that feeding steam-flaked corn did not change fat intake $[24,55]$. Zhong et al. [24] conducted a study to substitute ground corn in the feed with flaked corn using lactating Holstein cows, but there was no difference in fat digestibility according to the substitution level. Rastgoo et al. [55] compared the nutrient digestibility of Holstein dairy calves fed with ground and steam-flaked corn and observed no difference in fat digestibility. However, Joy et al. [56] reported a decrease in fat intake, similar to our results but nonetheless, stated that the reason for this was unclear. Most of the previous studies focused on CP or starch for flaked corn and ground corn, and since the research results on fat intake are not clear, further studies are needed to determine the cause for differences in fat intake.

To summarize, an increase in gelatinization through more intensive flaking increased the rate of rumen fermentation of flaked corn but did not increase the total ruminal available fraction. Compared with ground corn, flaked corn may be less digestible without sufficient particle size reduction by mastication, leading to lower total tract nutrient digestibility. Considering the additional processing cost of flaking [57], feeding flaked corn may not be a beneficial feeding practice, especially when sufficient chewing is limited (e.g., a high intake level and feeding for a short period).

In conclusion, although an increase in gelatinization enhances the ruminal fermentability of flaked corn, flaking by itself may not sufficiently improve corn's degradability compared to grinding. Without proper particle reduction by cracking or chewing, ruminal degradability and total tract nutrient digestibility of flaked corn may be lower than that of ground corn. Therefore, unlike the common assumption that flaked corn provides more energy to ruminant animals than ground corn, the energy content of flaked corn needs to be discounted when mastication is limited, for example, at a high intake level.

\section{REFERENCES}

1. Theurer CB, Lozano O, Alio A, Delgado-Elorduy A, Sadik M, Huber JT, et al. Steam-processed corn and sorghum grain flaked at different densities alter ruminal, small intestinal, 
and total tract digestibility of starch by steers. J Anim Sci. 1999;77:2824-31. https://doi. org/10.2527/1999.77102824x

2. McAllister TA, Phillippe RC, Rode LM, Cheng KJ. Effect of the protein matrix on the digestion of cereal grains by ruminal microorganisms. J Anim Sci. 1993;71:205-12. https://doi. org $/ 10.2527 / 1993.711205 \mathrm{x}$

3. Beauchemin KA, McAllister TA, Dong Y, Farr BI, Cheng KJ. Effects of mastication on digestion of whole cereal grains by cattle. J Anim Sci. 1994;72:236-46. https://doi. org/10.2527/1994.721236x

4. Yang WZ, Beauchemin KA, Rode LM. Effects of barley grain processing on extent of digestion and milk production of lactating cows. J Dairy Sci. 2000;83:554-68. https://doi. org/10.3168/jds.S0022-0302(00)74915-0

5. Safaei K, Yang W. Effects of grain processing with focus on grinding and steam-flaking on dairy cow performance. In: Shields VDC, editor. Herbivores. London: InTechOpen; 2017. p. 117-33.

6. Galyean ML, Wagner DG, Owens FN. Corn particle size and site and extent of digestion by steers. J Anim Sci. 1979;49:204-10. https://doi.org/10.2527/jas1979.491204x

7. Lykos T, Varga GA. Effects of processing method on degradation characteristics of protein and carbohydrate sources in situ. J Dairy Sci. 1995;78:1789-801. https://doi.org/10.3168/jds. S0022-0302(95)76804-7

8. Rémond D, Cabrera-Estrada JI, Champion M, Chauveau B, Coudure R, Poncet C. Effect of corn particle size on site and extent of starch digestion in lactating dairy cows. J Dairy Sci. 2004;87:1389-99. https://doi.org/10.3168/jds.S0022-0302(04)73288-9

9. Ramos $\mathrm{BMO}$, Champion M, Poncet $\mathrm{C}$, Mizubuti IY, Nozière P. Effects of vitreousness and particle size of maize grain on ruminal and intestinal in sacco degradation of dry matter, starch and nitrogen. Anim Feed Sci Technol. 2009;148:253-66. https://doi.org/10.1016/j.anifeedsci.2008.04.005

10. Firkins JL, Eastridge ML, St-Pierre NR, Noftsger SM. Effects of grain variability and processing on starch utilization by lactating dairy cattle. J Anim Sci. 2001;79:E218-38. https://doi. org/10.2527/jas2001.79E-SupplE218x

11. Lee SY, Kim WY, Ko JY, Ha JK. Effects of corn processing on in vitro and in situ digestion of corn grain in Holstein steers. Asian-Australas J Anim Sci. 2002;15:851-8. https://doi. org/10.5713/ajas.2002.851

12. Lee RW, Galyean ML, Lofgreen GP. Effect of mixing whole shelled and steam flaked corn in finishing diets on feedlot performance and site and extent of digestion in beef steers. J Anim Sci. 1982;55:475-83. https://doi.org/10.2527/jas1982.553475x

13. Zinn RA. Influence of flake density on the comparative feeding value of steam-flaked corn for feedlot cattle.J Anim Sci. 1990;68:767-75. https://doi.org/10.2527/1990.683767x

14. Huntington GB. Starch utilization by ruminants: from basics to the bunk. J Anim Sci. 1997;75:852-67. https://doi.org/10.2527/1997.753852x

15. Harvatine DI, Firkins JL, Eastridge ML. Whole linted cottonseed as a forage substitute fed with ground or steam-flaked corn: digestibility and performance.J Dairy Sci. 2002;85:1976-87. https://doi.org/10.3168/jds.S0022-0302(02)74274-4

16. Guyton AD, McKinney JM, Knowlton KF. The effect of steam-flaked or dry ground corn and supplemental phytic acid on phosphorus partitioning and ruminal phytase activity in lactating cows. J Dairy Sci. 2003;86:3972-82. https://doi.org/10.3168/jds.S0022-0302(03)74008-9

17. Cooke KM, Bernard JK, West JW. Performance of dairy cows fed annual ryegrass silage and corn silage with steam-flaked or ground corn. J Dairy Sci. 2008;91:2417-22. https://doi. 
org/10.3168/jds.2007-0715

18. Scott TL, Milton CT, Erickson GE, Klopfenstein TJ, Stock RA. Corn processing method in finishing diets containing wet corn gluten feed. J Anim Sci. 2003;81:3182-90. https://doi. org $/ 10.2527 / 2003.81123182 \mathrm{x}$

19. Corona L, Rodriguez S, Ware RA, Zinn RA. Comparative effects of whole, ground, dry-rolled, and steam-flaked corn on digestion and growth performance in feedlot cattle. Appl Anim Sci. 2005;21:200-6. https://doi.org/10.15232/S1080-7446(15)31203-1

20. Macken CN, Erickson GE, Klopfenstein TJ, Stock RA. Effects of corn processing method and protein concentration in finishing diets containing wet corn gluten feed on cattle performance. Appl Anim Sci. 2006;22:14-22. https://doi.org/10.15232/S1080-7446(15)31056-1

21. Owens CE, Zinn RA, Hassen A, Owens FN. Mathematical linkage of total-tract digestion of starch and neutral detergent fiber to their fecal concentrations and the effect of site of starch digestion on extent of digestion and energetic efficiency of cattle. Appl Anim Sci. 2016;32:53149. https://doi.org/10.15232/pas.2016-01510

22. Yu P, Huber JT, Santos FAP, Simas JM, Theurer CB. Effects of ground, steam-flaked, and steam-rolled corn grains on performance of lactating cows. J Dairy Sci. 1998;81:777-83. https://doi.org/10.3168/jds.S0022-0302(98)75634-6

23. Dhiman TR, Zaman MS, MacQueen IS, Boman RL. Influence of corn processing and frequency of feeding on cow performance. J Dairy Sci. 2002;85:217-26. https://doi.org/10.3168/ jds.S0022-0302(02)74070-8

24. Zhong RZ, Li JG, Gao YX, Tan ZL, Ren GP. Effects of substitution of different levels of steam-flaked corn for finely ground corn on lactation and digestion in early lactation dairy cows.J Dairy Sci. 2008;91:3931-7. https://doi.org/10.3168/jds.2007-0957

25. Mathew B, Eastridge ML, Oelker ER, Firkins JL, Karnati SKR. Interactions of monensin with dietary fat and carbohydrate components on ruminal fermentation and production responses by dairy cows.J Dairy Sci. 2011;94:396-409. https://doi.org/10.3168/jds.2010-3580

26. Macken CN, Erickson GE, Klopfenstein TJ. The cost of corn processing for finishing cattle. Appl Anim Sci. 2006;22:23-32. https://doi.org/10.15232/S1080-7446(15)31057-3

27. AOAC [Association of Official Analytical Chemists] International. Official methods of analysis of AOAC International. 18th ed. Gaithersburg, MD: AOAC International; 2005.

28. AOAC [Association of Official Analytical Chemists] International. Official methods of analysis of AOAC International. 18th ed. Gaithersburg, MD: AOAC International; 2006.

29. AOAC [Association of Official Analytical Chemists] International. Official methods of analysis of AOAC International. 17th ed. Gaithersburg, MD: AOAC International; 2000.

30. Zhu L, Jones C, Guo Q, Lewis L, Stark CR, Alavi S. An evaluation of total starch and starch gelatinization methodologies in pelleted animal feed.J Anim Sci. 2016;94:1501-7. https://doi. org/10.2527/jas.2015-9822

31. Sun L, Lee M, Jeon S, Seo S. Evaluation of the associative effects of rice straw with timothy hay and corn grain using an in vitro ruminal gas production technique. Animals. 2020;10:325. https://doi.org/10.3390/ani10020325

32. Goering HK, Van Soest PJ. Forage fiber analyses: apparatus, reagents, procedures, and some applications. Washington, DC: Agricultural Research Service, US Department of Agriculture; 1970.

33. Ørskov ER, McDonald I. The estimation of protein degradability in the rumen from incubation measurements weighted according to rate of passage. J Agric Sci. 1979;92:499-503. https://doi.org/10.1017/S0021859600063048

34. Seo S, Jeon S, Ha JK. Guidelines for experimental design and statistical analyses in animal 
studies submitted for publication in the Asian-Australasian Journal of Animal Sciences. Asian-Australas J Anim Sci. 2018;31:1381-6. https://doi.org/10.5713/ajas.18.0468

35. NRC [National Research Council]. Nutrient requirements of small ruminants: sheep, goats, cervids, and new world camelids. Washington, DC: National Academy Press; 2007.

36. Armbruster S. Steam flaking grains for feedlot cattle: a consultant's perspective. In: Proceedings of the Cattle Grain Processing Symposium; 2006; Tulsa, OK.

37. Tremere AW, Merrill WG, Loosli JK. Adaptation to high concentrate feeding as related to acidosis and digestive disturbances in dairy heifers. J Dairy Sci. 1968;51:1065-72. https://doi. org/10.3168/jds.S0022-0302(68)87125-5

38. Yuan J, Wan X. Multiple-factor associative effects of peanut shell combined with alfalfa and concentrate determined by in vitro gas production method. Czech J Anim Sci. 2019;64:352-60. https://doi.org/10.17221/94/2019-CJAS

39. Hales KE, McMeniman JP, Leibovich J, Vasconcelos JT, Quinn MJ, May ML, et al. Effects of varying bulk densities of steam-flaked corn and dietary roughage concentration on in vitro fermentation, performance, carcass quality, and acid-base balance measurements in finishing steers.J Anim Sci. 2010;88:1135-47.https://doi.org/10.2527/jas.2009-2400

40. Qiao FQ, Wanng F, Ren LP, Zhou ZM, Meng QX, Bao YH. Effect of steam-flaking on chemical compositions, starch gelatinization, in vitro fermentability, and energetic values of maize, wheat and rice. J Integr Agric. 2015;14:949-55. https://doi.org/10.1016/S20953119(14)60913-8

41. France J, Dijkstra J, Dhanoa MS, Lopez S, Bannink A. Estimating the extent of degradation of ruminant feeds from a description of their gas production profiles observed in vitro: derivation of models and other mathematical considerations. Br J Nutr. 2000;83:143-50. https://doi. org/10.1017/S0007114500000180

42. Kokić BM, Lević JD, Chrenková M, Formelová Z, Poláčiková M, Rajský M, et al. Influence of thermal treatments on starch gelatinization and in vitro organic matter digestibility of corn. Food Feed Res. 2013;40:93-9.

43. Gorocica-Buenfil MA, Loerch SC. Effect of cattle age, forage level, and corn processing on diet digestibility and feedlot performance. J Anim Sci. 2005;83:705-14. https://doi. org/10.2527/2005.833705x

44. Chrenková M, Formelova Z, Ceresnakova Z, Dragomir C, Rajsky M, Cismileanu A, et al. Rumen undegradable protein (RUP) and its intestinal digestibility after steam flaking of cereal grains. Czech J Anim Sci. 2018;63:160-6. https://doi.org/10.17221/74/2017-CJAS

45. Dakowski P,Weisbjerg MR, Hvelplund T. The effect of temperature during processing of rape seed meal on amino acid degradation in the rumen and digestion in the intestine. Anim Feed Sci Technol. 1996;58:213-26. https://doi.org/10.1016/0377-8401(95)00868-3

46. Fiems LO, Cottyn BG, Boucque CV, Vanacker JM, Buysse FX. Effect of grain processing on in sacco digestibility and degradability in the rumen. Arch Tierernaehrung. 1990;40:713-21. https://doi.org/10.1080/17450399009428420

47. Singh N, Mudgal VD. Protein requirements of castrated Beetal goat bucks. Small Ruminant Res. 1991;4:127-35. https://doi.org/10.1016/0921-4488(91)90059-Y

48. Mishra S, Rai SN. Influence of varying RDP: UDP ratios in diets on digestion, nitrogen utilization and milk production efficiency in goats. Small Ruminant Res. 1996;20:39-45. https:// doi.org/10.1016/0921-4488(95)00783-0

49. Akhtar MU, Qayum A, Shan A, Chou S, Jo H, Shah SWA, et al. Influence of different dietary rumen degradable protein concentrations on nutrient intake, nutrient digestibility, nitrogen balance, blood urea nitrogen and milk yield of lactating beetal goats. Pak J Zool. 2020;52:213-21. 
https://dx.doi.org/10.17582/journal.pjz/2020.52.1.213.221

50. Wu Z, Ohajuruka OA, Palmquist DL. Ruminal synthesis, biohydrogenation, and digestibility of fatty acids by dairy cows. J Dairy Sci. 1991;74:3025-34. https://doi.org/10.3168/jds.S00220302(91)78488-9

51. Palmquist DL. Influence of source and amount of dietary fat on digestibility in lactating cows. J Dairy Sci. 1991;74:1354-60. https://doi.org/10.3168/jds.S0022-0302(91)78290-8

52. Alexander G, Prabhakara Rao Z, Prasad JR. Effect of supplementing sheep with sunflower acid oil or its calcium soap on nutrient utilization. Asian-Australas J Anim Sci. 2002;15:128893. https://doi.org/10.5713/ajas.2002.1288

53. Delobel A, Fabry C, Schoonheere N, Istasse L, Hornick JL. Linseed oil supplementation in diet for horses: effects on palatability and digestibility. Livest Sci. 2008;116:15-21. https://doi. org/10.1016/j.livsci.2007.07.016

54. Owens FN, Zinn RA, Kim YK. Limits to starch digestion in the ruminant small intestine. J Anim Sci. 1986;63:1634-48. https://doi.org/10.2527/jas1986.6351634x

55. Rastgoo M, Kazemi-Bonchenari M, HosseinYazdi M, Mirzaei M. Effects of corn grain processing method (ground versus steam-flaked) with rumen undegradable to degradable protein ratio on growth performance, ruminal fermentation, and microbial protein yield in Holstein dairy calves. Anim Feed Sci Technol. 2020;269:114646. https://doi.org/10.1016/j.anifeedsci.2020.114646

56. Joy MT, DePeters EJ, Fadel JG, Zinn RA. Effects of corn processing on the site and extent of digestion in lactating cows. J Dairy Sci. 1997;80:2087-97. https://doi.org/10.3168/jds.S00220302(97)76154-X

57. Peters TM. Comparing cost versus benefits of corn processing for feedlot cattle. In: Proceedings of Cattle Grain Processing Symposium; 2006;Tulsa, OK. 